\title{
Zoning protection models and eco-development areas of Karla, Trikala and the Sporades Islands in Thessaly, Greece
}

\author{
E. Koutseris \\ University of Thessaly, \\ Department of Planning and Regional Development, Greece
}

\begin{abstract}
The E.U. Directive of $92 / 43$ on habitat aims to contribute to the conservation/preservation of biodiversity through the maintenance of habitats and species of wild fauna and flora. Preservation is achieved via the 'Natura 2000 ' network, so that the protection of natural biotopes and of the species in the 'European area of Concern' (E.C.) is ensured. A similar study was drawn up for the region of 'Karla' (Mavrovouni - Karla - Kefalovriso), the 'Alonnissos marine park of the Northern Sporades', 'Trikala' (Aspropotamos, Mount Kerketio or Koziakas, the Antihasia Mountains-Meteora) and some other areas of less importance, in Thessaly, Greece. Moreover, the 'Natura 2000' network also includes 'Special Protected Areas' (SPA) which are determined according to the 79/409/EOK directive on ornithofauna. Briefly, the present paper is a contribution to the application of E.U. environmental programs and the emerging management protection problems in Thessaly, Greece and especially one application of some protection of delimitation-zoning models recorded, with examination of novel control policies. Should this be achieved by the protection concept or by the enlargement of zone protection areas.

Keywords: environmental E.U. policies, protection zoning-delimitation, regions of eco-development or controlled activities area, sustainable development, Working Team 'Natural Environment'.
\end{abstract}

\section{Introduction}

The sixth action programme for the environment, which is currently being adopted, sets out the priorities for the European Community up to the year of 
2010. Measures to achieve some priorities are outlined, such as the improvement of the application of environmental legislation, ensuring that other community policies take greater account of environmental considerations (Christopoulou and Trisoni [1] E.U. Directive/92/43 [2], Kotios [3], Koutseris [4]).

The application of the Greek 'Natura 2000' program was divided in three phases: Phase A (1992-1995), during which the inventory and evaluation of regions was accomplished; Phase B (up to 1998), during which a list of regions of community importance was created; and Phase C (up to July 2004), during which the 'Special Areas of Maintenance or Conservation' (SAC) were to be officially delimited and classified as habitat areas and the priorities for their conservation and the rehabilitation were to be determined. In addition, SPA, contained in the Natura 2000 list was delimited, though these areas focused on the protection of birds, based on directive 79/409/EEC (Ministry of Greek environment, EPP.ER [5], Koutseris [6]). The second research program of the E.U., the 'Corine Biotopes Project', led to the recording of the most important biotopes in Greece (Ministry of Greek environment, EPP.ER [5]).

In the present article we present some models concentrating on the subject of the acceptance and the impacts of the application of the Natura 2000 - SPA regions and on the matter of water resources management and the use of rural space. Furthermore some regions, as eco - development areas are proposed around Natura 2000 and SPA regions in Thessaly. The contribution of the Working Team 'Natural Environment' (WTNE) on the matter of consciousnessraising in Thessaly is following. Finally we evaluate the models used in casestudies in Thessaly regarding its influence on E.U. and Greek environmental policies for management-protection as well as on the new CAP and the results of the case studies regional management, under the institutions or committees of the 'Natura 2000, SPA' (Koutseris et al [7], Koutseris [8], Koutseris and Polysos $[9])$.

\section{Problems in the application of new E.U. protection policies in Thessaly, Greece}

The most important measures for environment protection were taken by the European Community with the Single European Act in 1987 and the treaty on the E.U. in 1992. These acts addressed important environmental problems particularly the ones caused by modern agriculture. Two of these problems were the waste of scattered veterinary surgeon units and of urban sewage. There was also damage to flora, fauna, soil and waters due to the uncontrolled use of pesticides (Kungolos et al [10]). Human health was also severely affected due to surges in agricultural production and the attendant remains of pesticides and fertilizers in agricultural products, pollution of potable water, erosion of soil, and imbalances in rural-urban settlements and ecosystems. The intensive model of monocultures caused irrational and abusive use of fertilizers and the over pumping of aquatic resources, with the consequent salinization of cultivated soil, as well as the salinization of certain coastal regions (Kungolos et al [11]). Underground waters were polluted, mainly from nitrates but also from 
phosphoric salts, and there was an exhaustion of underground aquatic horizons in regions with hydrous cultures caused by a network of drillings (Podimata et al [12]). At the same time, two new protection issues arose: the network Natura 2000, SPA and the management of water for Greece and Thessaly. The first relates to the present study, since it relates to the problem of protection regions (Koutseris [13,14] and Koutseris and Polysos [9]).

Furthermore, according to the directive, 97/62/EE, 'on the technical and scientific readjustment of the directive 92/43 EEC', the member states were obliged to draw up a list of 'places of EC' in their country, which would constitute 'SAC' of the 92/43 of EEC, as well as 'Special Protected Regions of Preservation' (SPRP) of the directive 79/407/EEC, which will constitute the 'Natura 2000' network (Ministry of Greek environment, [15] and Ministry of Greek environment, EPP.ER. [5]). A total of 265 regions were included in this directive approximately $20 \%$ of Greek territory (Koutseris $[8,13]$ and Koutseris et al [7]). Under this initial effort in Thessaly, the most important regions the "artificial lake of Karla and Mavrovouni mount', the 'Alonnissos marine park of the Northern Sporades" and Trikala (Aspropotamos, Kerketio or Koziakas mount, the Antihasia Mountains-Meteora) and some other areas of less importance, were specified (Koutseris [4,16]). Problems associated with this effort were:

First: "The non-essential participation of local self-governments and local social and economic institutions in the choice of areas for protection" (Kotios [3], Koutseris et al [7], Koutseris [8]).

Second: An arbitrary territorial approach, based on the 92/43 Directive, for the determination and recording of certain habitat areas, was supported only by bibliographic references without local input. This was presented to the E.U. in 1995 by the Ministry of Greek environment, planning and public works (Y.PE.HO.DE), as a national list of the Natura 2000 regions in Greece.

Third: Though not dealt in details with this issue at present. The problem of water management, including pricing and cost-accounting of water systems based on the recent directive 2000/60/EU (Koutseris [16,17], Koutseris and Papavassiliou [18].

Fourth: The strictly protection concept or the enlargement by zoning of protection areas?

\section{Models of zoning protection in Thessaly and the novel control policies}

We must note that Greece signed the Ramsar (wetlands) treaty in 1974, the convention of Bern (wild life, habitats) in 1983, the protocol of Barcelona (pollution of Mediterranean) in 1986, the convention of Washington on the trade in species in 1992, the convention of Rio on biodiversity in 1992, the convention of Bonn on migratory species and the protection of the Mediterranean Seal in 1999 (Loukissas et al [19]).

The Region of Thessaly allocates a large variety of eco-hydrological reserve that covers on the one hand all the natural particularities of Greek space and on 
the other a big breadth of human activities. Particular gravity was given by the WTNE of Region Thessaly in three, between other examples, as models that can be described in "delimitation - zoning and competition of uses in Thessaly": us examples of controlled development, waters - mounts, new measures and Committee of Management (Koutseris [16]).

In the first model, the Lake Karla region has been the object of many studies (Figure 1). It has been characterized, via Special Environmental Study (SES) and according the Greek law (1650/1986), as an eco-development region. This region also constitutes, according to article 6 of directive 92/43/EEC, a SAC. It is also part of a system of protected regions under the application on one hand, of article 8 of the international convention of Rio on biological diversity and on the other hand, article 6 of the international convention of Bern on the conservation of wild life and the natural environment of Europe (Meliadis [20]).

The above also applies for other regions within the framework of directive 92/43/EEC. These areas have also been presented by the appropriate authorities to the European Committee, along with (SPRP), as proposed of "EC" regions which will constitute the network Natura 2000. The regions listed below include all the above characteristics and are included under the Ministry of the environment and public works plan (ETHIAGE [21], Koutseris [13], Christopoulou [22] and PEP [23]). The first call brief lie 'Karla' contended:

A) Mount Mavrovouni and the marine region surrounding it, which has been included in the European network of the protected region "Natura 2000" (see Figure, 1, A strictly protection and B protection).

B) The region affected by the work of re-creating Lake Karla which consists of the region of the re-flooding of the lake and the immediately adjacent region (ibid, 1, B protection).

C) The wider region, flat and hilly, which is directly connected to the lake and constitutes its drainage basin (ibid, $1, \Gamma$ controlled activities, Koutseris [24]).

Particular importance was given by the WTNE to the island region (Sporades and Erimonissa island), which has been proposed as a model for the rest of the country. Eighty-eight percent of the region has been defined as a marine park, and is subject to the regulations of Presidential Greek law (519/92) concerning the Northern Sporades. Some islands are considered important regions for birds in Greece according to Community directive 409/79. In addition, the island 'Piperi' has been characterized by ministerial decision 290095/7950/1997, as a natural preserve and monument. The marine park Sporades and Erimonissa region is at the heart of the national program for the protection of the Mediterranean seal (PEP [23], see Sporades islands in Figure 1, including the park). Briefly the reasons are the following (KEKANAM [25]):

1. It is the largest in size, not only in the region of Thessaly, but also in Greece and particularly as an island-sea combination. The largest part of the region (94\%) is covered by sea. Its total area includes $251.440 \mathrm{Ha}$ and its median altitude is 285 meters. 2. It possesses international importance due to the presence of endemic species (e.g. UN model since 1998, see Koutseris and Polysos [9] and Koutseris and Papavassiliou [18]). 3. It attracts the long-lasting interest of the scientific community and of various ecological organizations, 
which have both national and international influence on the promotion and protection of the region (Ministry of Greek environment - Y.H.O.P. [26]. 4. The level of development of studies on this region. 5. The more recent $(6 / 2003)$ establishment of the Management Commitee by legislation. 6. The presence of accumulated positive and negative effects during the 20 -year-old management of the region.

Apart from the SES, which has existed since 1995, another important study by the local government organization of the Prefecture of Magnesia (KEKANAM, [25]) was conducted in 2001. This study was carried out by the 'laboratory of tourism' of the department of planning and regional development of the University of Thessaly. The title was the "Promotion of the marine park of the Northern Sporades and its integration into the social web". In this study, a management Committee was proposed, though it was not incorporated at that time by the government, either in the recent law (P. Low 621/19-6-03) or in the law 939/8-7-03 (Koutseris in the KEKANAM [25] and Koutseris [4,8], Ministry of Greek environment, EOE. Mom [27]).

Others two SES, us a third model, were in Thessaly applied. One by Ecoconsultants bureau published on 1999 and defined on 2001 for Aspropotamos (GR.1400001) and Kerketio or Kosiakas Mountains (GR.1440002), where the protection areas are for an even wider region. This large space at the same time, in the European ecological network of special zones which will be named "Natura 2000" contended (EPP.ER. [5]). According to the SES, the protection regime was on the delimitation - zoning of two zones based:

Zone A: all the forest areas, as regions of protection of nature according to the Greek law 1650/1986 contended (Marossa, Koutiana, Pertuliotika Libadia). Zone $\mathrm{B}$ : the protection regime according to the above law, us eco-development region proposed, also the Zone An included (EP.PE.R. [5], Koutseris et al [7]).

The second SES, of the third model, is Antihasia Mountains-Meteora. Zone A: a large area of SPA for the maintenance and enrichment of existing 'ornithofauna' habitats, especially Milvus migrans and Neophron percnopterus, that fronting disappearances.

Zone B: the protection regime according to the above law, us ecodevelopment region proposed, that also the Zone A included. This area a wider part of the municipality of Kalampaka and Trikala covered.

\section{Application of zoning: delimitation protection and the contribution of the working-team on the natural environment in Thessaly Greece}

In the EEC in 1992 an important step was made towards "sustainable development", the object of which is not only the protection of the environment but also the sustainable future growth. A new policy, focusing on preventive action, placed particular emphasis on the more rational use of resources, as well as on the reduction and the more effective use of the products, themselves (Koutseris [13], Koutseris and Polysos [9]). 
The extent of the area covered by "Natura 2000" in Thessaly was roughly $220,000 \mathrm{H} \alpha(16-20 \%)$. The creation of a European ecological network of special zones which will be named "Natura 2000" is anticipated for these regions. These, according to the criteria of the 92/43 directive, were classified by the Greek Centre of Biotopes-Wetland into three categories of A., B., and C., significance. In some of the mountainous and island areas, special environmental studies have been carried out within the framework of Greek national law (1650/86), mentioned before (Koutseris [8] and Koutseris and Polysos [9]).

In addition to E.C. regions, some plans for common ministerial decisions (CMD) were drawn up recently in Thessaly (Koutseris in KEKANAM [25], Ministry of Greek environment, EOE. Mom [27]). The national goals for these regions are the maintenance, management and promotion of the natural environment of a specific area, as well as of the wider region. They include: 1 . The maintenance and enrichment of existing 'ornitho-fauna' habitats. 2. The reinforcement of local development via the rational use of natural resources and particularly, the aquatic resources of the region. 3. The development of 'soft' forms of tourism, us eco- and agro-tourism. 4. The education and consciousnessraising of people and public institutions towards the harmonious coexistence of human and natural activities. 5. A redefinition of the limits of territorial competence of the institutions of management, etc (PEP [23]).

Eco-development is defined by the terms the Greek national law (1650/86) and the boundaries of a region under consideration are based on the special landplanning plan (SLP) or on a (SES). Most of the SES studies have been carried out within the framework of Greek national law mentioned above. Regional plans consider the special characteristics of a region and seek the protection of nature through careful delimitation of land uses and the management of exploitation for an even wider region, so as to insure that the natural resources should not be exhausted, but should maintain their efficiency or yield 'forever', according to the theory of sustainability (Koutseris [24]).

For the completed and effective protection and maintenance of itself and its values it was separated in individual areas. These concern extensive regions that include villages or settlements that present on one side, problems of intensive agriculture and de-valorization, so that protection is required and on the other side, particular value and interest because of ecological geomorphologic, biological, scientific importance that require maintenance (Koutseris and Polysos, [9]).

What did the Working-Team discover? The proposed new policies are related with the observed lack of regulations for certain questions, which concern mainly the improvement of management of natural resources. The frames of controls concerning the built-up growth and the precaution of environmental sensitive regions, as they are described more, they are satisfactorily considered provided that they are applied with right way (Koutseris [24]).

Unfortunately however, the expected consultations with local communities on the terms and the restrictions of 'Natura 2000' did not take place, when the first (scientific) list was designed in 1995. In many cases, lines had already been drawn on the map without due consideration of local needs and insights, e.g., 
Pelion (see Christopoulou [22]). Previous advice of E.U. executives (see Zouljen's speech in 1995) from the eleventh general administration on the great importance of the participation of citizens in 'protected regions, defined as SAC' was simply ignored (Koutseris, et al [7], Koutseris, [8].

The integration of regions into the 'Natura 2000' network has been taken for granted and is henceforth law. The concerns of certain groups could, however, be reduced if there were a study of the benefits of integration (or not) of those regions and, in particular, in relation to the competition or conflict of land uses. Such a study should address, in particular, the question of non-use in relation to long term benefit - damage something that would be addressed by this investigation through its political and administrative or managerial solutions (Koutseris [13,24]).

During 2003 and some of 2004, the WTNE tried to cover the current lack of briefing and consciousness-raising through multiple meetings both in the capital of Thessaly, Larissa and in 15 regions of special interest to environmental planning. Simultaneously, e-mails concerning general and specific proposals on environmental issues were sent to various institutions and to all the municipalities of Thessaly (Koutseris [11] or Koutseris et al [7]). During 2003 the WTNE, developed seven basic proposals for the 'Natura' regions and for water resources management in the region of Thessaly. The results from a total of 20 studies may be seen in various writings, articles, questionnaires and recordings (Koutseris et al [7] and Koutseris and Polysos [9]).

Apart from briefing-informing, the goal of the WTNE was also the determination of activities within the framework of the 'Strategic regional and environmental planning for the sustainable development of Thessaly' (PLAN) for the "Natura 2000" regions and for the aquatic resources of Thessaly. Planning focused more on the sectors that have an impact on the natural environment, while keeping in mind all of the diagnoses and regional policies, the Land-Planning Plan (LP/P), and the policies for rural space regarding the management of water and soil, as well as urban planning in rural areas (Koutseris and Polysos [9], Koutseris [28], Koutseris [29]).

The proposed PLAN was not an end in itself, but rather a means for the intensification and future guarantee of development This development, however must be supported by theories of sustainability. A general objective is that the development and the protection of the natural, social and cultural environment should become coordinated, so that, over time, the greatest possible economic profits for the region would be achieved. In other words, the main objective of the plan must be the minimization of negative impacts along with a parallel maximisation of advantages for the local economy, society and environment (Koutseris and Polysos [9], Koutseris [30]).

There are seven regions from the national list of Natura (dir.92/43) and SPA (dir. 79/409) found in Thessaly and recorded by the Working-Team. These include (see Figure 1): 1. Magnesia, the most important and largest related to islands and the sea (see Figures 2 and 3); 2. Trikala (Aspropotamos, Kerketio or Koziakas mount, the Antihasia mountains-Meteora); 3. Mainland Magnesia and Larissa (Karla and the flat area, Pelion mount, Kouri Almiros). 
The following are less important on human activities areas 4. The plains and mountains around Trikala and Larissa, including (stena Kalamakiou, river Pinios - Antihasia mountains); 5. The aesthetic forest of Tembi Valley; 6. Ossa (Lower Olympos); 7. Karditsa (region of lake Tavropos, Agrafa).

There are, however, also trans-regional units. It should be noted that various local institutions seek the integration of the intermediary space between the regions in Natura (e.g. the Municipality of Malakassi and westwards). Many questions also arise regarding the proper management of these regions. Will they constitute self-existent entities? Will they be incorporated with the remainder?

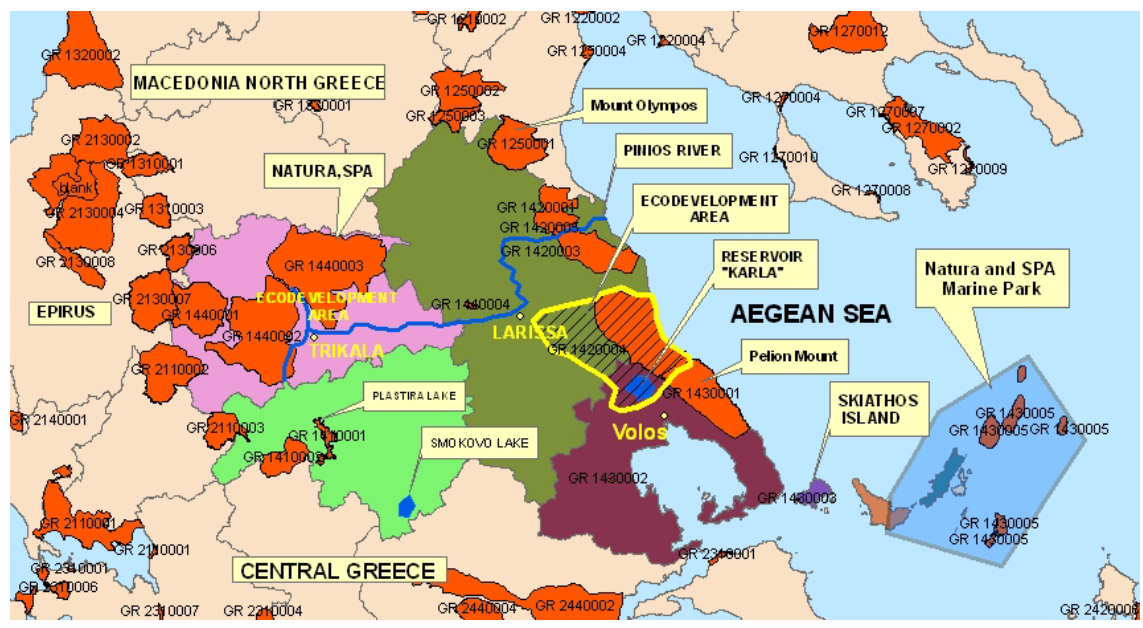

Figure 1: Source: the same treatment with enrichment, from Koutseris, $2006 a$.

\section{Proposed eco- development areas with Natura 2000, spa and protection zones in Thessaly}

The observed lacks in the sector of maintenance (or even reduction) the levels of consumed natural resources (energy or other) concern (a) regulations in local level for the important repercussions of environment, (b) regulations for the under protection regions, (c) regulations on restriction of consumption of energy (electric and humid fuels) and natural resources, (d) recycling and re-use of waste, (e) recording of levels of pollutants, (f) water management in the total of region or even in the wider Region Thessaly and (g) systematic follow-up of habitat and not enacted interventions in cases of problems (Koutseris and Polysos [9]).

In the regions of eco-development or controlled development the minimum plot size for building on agricultural land should be raised to $0.8-2.0 \mathrm{Ha}$, instead of the $0.4 \mathrm{Ha}$, which is in effect today. Thus the value of land within municipal boundaries would rise and the value of agricultural land would decrease. 
The $250 \mathrm{~m}$ zone around municipalities would become a controversial question, but the more rational expansion of settlements should be one effect (see Figure 1, Koutseris et al [7], Koutseris [8,16,29]).

\section{Evaluation of the models: a case study in Thessaly}

All the 'Controlled Development' areas (e.g., around technical reservoir of Karla) are examined, including the water control systems (see Figure 1). Attention is given to the Management Committee of the three regions and its success in direction of the development and management of water resources as specified by Natura 2000 and SPA and/or eco-development by protection zoning-delimitation (Koutseris [24]).

Within the framework of the 3rd Community structural funds (CSF), related to the 'Natura 2000' regions, measures and actions have been financed (PEP., EP.PER of the Ministry of the environment, planning and public works, Life and Leader). These measures were aimed on the promotion of rural, ecological, educational and scientific tourism, on attracting visitors, on the promotion of employment in many sectors and on the production of environmental products and services (PEP. [19], Koutseris [29,30]).

However, all this would require the strategic reformation and reconstruction of the European agricultural model from individual production to a more qualitative, i.e., more collective and environmentally friendly system of production and consumption, all of which would require an increase in E.U. funding (Koutseris [29]).

Taking into consideration developments and tendencies in the WTO, E.U. regulation $1257 / 99$ and the new intermediary revision of CAP 2003 promote environmental considerations in the rural sector even more, connecting the provision of aid with adherence to the rules of 'equitable agricultural practice' which mainly concern: the protection of water, controls in the use of nitrate fertilizers and of pesticides, the protection of the 'Natura 2000' regions and of habitats and the incorporation of environmentally friendly methods of production into the quality of products.

This would require a reorientation in E.U.-Funds in favor of viable laborintensive agriculture and know-how, which is at the same time environmentally friendly. Simultaneously there must drastic reinforcement of laws concerning the commercial labeling of quality products, promotion of institutions for interdisciplinary and inter-professional regional collaboration and programs for the environmental consciousness-raising of consumers.

The new CAP (June 2003 and April 2004) takes into consideration both the consumer and tax payer-citizen, while at the same time, giving European farmers the capacity to produce whatever the market demands. In the future, financial aid to agriculture will be given in part irrespective of the volume and type of production. In order to avoid the abandonment of production, member states can retain certain types of aid under specific conditions (Koutseris et al [7], Koutseris and Papavassiliou [18], Koutseris [29,30]). 


\section{Results of the case studies}

There is a major question relative to the management of all those protection regions. Generally, it is essential that the various existing, as well as the future or proposed activities will be in harmony in any given area. An agency or management committee of the biotope should be responsible for this, at both the national level, as well as in any given protection region (E.U. directive/92/43).

The necessary support regulations that should be followed by protection zoning-delimitation are (Meliadis in Koutseris et al [7], Koutseris [29,30,31], Koutseris [32]): Integrated interventions in the sector of ecological and rural tourism, concentrating on biotopes (agro-tourist units, etc.). Strengthening the role of the local community and the active participation of citizens. Attracting private investment in alternative tourism. Strengthening environmental programs aiming at consciousness-raising of citizens on issues relating to the natural environment, ecotourism etc. (Koutseris [4,8,29,30]).

The creation of these committees has constituted a national political choice for the last 20 years Greek law (1650/86, law 2742/99 and law 3044/02). Among the 25 committees in Greece, two of them were established recently (article 13 national law 3044/02) and have been called 'the Management Committee Karla' and 'the national sea park of Alonnissos-Northern Sporades'. Us all ready mentioned, the extent of the territory for each committee can be expanded or be coterminous with the limits of the each eco-development region. According a decision taken by the Ministry of Greek Environment, the administrative council will consist of 7-11 members, whose term of office is three-years, with the possibility of renewal (Koutseris [29]).

According to the WTNE, management and government control is not the same thing. The government is important for policing and eliminating violations so that protection may be achieved. However, there must also be an improvement in the briefing of local communities for land use planning, for consciousnessraising, for publicity and promotion of tourist packets with alternative forms of tourism, etc. Participative Administration should be established to include committees at all levels of government (Local, Prefecture, and Region). The role of government would not be diminished thereby, but would, in fact, be strengthened, either through being referenced by the committees, themselves (law-ministry), or as a controlling mechanism (forest inspection). Thus, local participation must be strengthened, more at the level of management committee branches than at the level of ministries, so that it would have both a local and regional character, and would be compatible with both public and private interests (law 2742/99, PEP [23], Koutseris et al [7], Koutseris [30]).

Based on, the experience of the newly established committees in Skoinia, Zakynthos and the above national marine park of Alonnissos-N. Sporades and from the aggregate of proposals from other studies, the Working-Team, has proposed a hierarchy of homogeneous regions which would unify many 'Code-Natura 2000' regions, with or without their wider eco-development areas and the creation of a hierarchy of administrative committees to manage them (Ministry of Greek Environment, EOE. Mom. [27], Ministry of Greek Environment, YXOP. [26], see also Koutseris, et al [7] and Koutseris [8,30]). 
We pointed out the main problems that must be faced in Eastern Thessaly. These include: the management of solid waste, the intense problem of overexploitation of water resources, the need for controlled development of expanding settlements in the eco-development regions and of human intervention in nature, and the need for partial zoning and regulating of areas under intense use from human activity (Koutseris [31]).

Certain conclusions were reached. These referred to principles on the general direction of PLAN, based on the ecological reserves, including a new strategy for managing natural and aquatic resources, as well as construction projects and regulations in Thessaly, such as water supply for cities, restrictions on drillings, alternate sources for thousands of cubic metres of water, maintenance of the viability of agricultural production, and, finally, the creation of an Institute for the management of resources and the environment in Thessaly.

Three general conclusions were reached. These adress the need to establish priorities for the use of water up to the year 2010, interventions needed to regulate the demand, use and management of water and planning for the creation of projects to collect surface waters. Finally, it was proposed that the number of areas and resources to be protected should be increased (Koutseris [24,29,30]). So seven proposals were made, relating to: 1 . Sustainable tourist development in Thessaly. 2. Sustainable hydro-enviromental development. 3. A hierarchy of environmental planning within the Prefectures. 4. Choice of the regions for action. 5. Relating regional action priorities to the strategy of the plan. 6. Zoning. 7. The need for a national zoning and energy policy. Finally, it is conluded from the people interviewed that:

1. the general population agrees, generally with the European environmental policies, but they disagree with the way the Natura regions were integrated.

2. They prefer the classification of land use into intensive, extensive and mixed production regions; await an increase in financial support from the E.U., including compensatory measures that would also include support for short-term exploitation/use of resources; are in favour of viable labor-intensive agriculture and await intstruction on how to accomplish it; and, finally, support a charge for the use of water even for farmers (Koutseris [32]).

3. They support the idea of eco-Development Regions and/or Controlled Development, as well as the increase of minimum required land area for building outside settlements from $0,4 \mathrm{Ha}$, to $0,8 \mathrm{Ha}$ and $2 \mathrm{Ha}$, but only after direct extensions of settlements. While no one wishes for total central control in the Managemant Committee, they prefer that for each code 'Natura' region, with or without its wider zone of eco-development, a Managemant Committee should also be established even should there also be a central Management Committee, as provided for by law 2742/99 (Koutseris [30]).

\section{References}

[1] Christopoulou O., Trisoni E. (2005): "Planning of human activities based on views of local communities in protected areas: The case of mountain Pelion, Greece". In Discussion Paper Series, 11(9), 141 162. Un. Thessaly, Volos 
[2] E.U. Directive/92/43. (1992): "Natura 2000”, 'on habitats'. In EEEK, Brussels.

[3] Kotios A. (2002): Restrictions and capacities of development activities in the 'Natura regions'. In Conference Paper 26-4-02, dep. of P and RD. Un. Thessaly. Volos (in Greek)

[4] Koutseris E. (2003): "General Directions of the Natura 2000-SPA regions and water resource management in Thessaly (dir.2000/60/EU): management Committees and regional - agro- environmental measures in the new CAP'. In Newspaper 'Neos Tipos'. July, extensive publication. Volos

[5] Ministry of Greek Environment, EPP.ER. (2001): "Environmental operational programme". Internet, http://www.minenv.gr

[6] Koutseris E. (2005a): "Land-Sustainable environmental planning: natural resource management and protection-preservation". Notes. TEF. Department of Administration and Works management. Larissa, pg 288 (in Greek)

[7] Koutseris E. et al (Scientific in charge, 2004): Regional Environmental Strategic Plan of Sustainable Development of Thessaly (RESP of SD in Th): based on the 'Natura' area and water researches management (dir. 2000/60/EU), WTNE of Region Thessaly. Larissa, p. 301 (in Greek)

[8] Koutseris E. (2004): Environmental social consensus in Thessaly: an ex post evaluation of the acceptance and impacts of the application of the 'Natura 2000 - SPA' regions, and water management resources, in the new prospect of rural space». Eds. Erodhios. Thessaliniki, p. 180 (in Greek)

[9] Koutseris E., Polysos S. (2005): "Water resources exploitationvalorization in the context of environmental policies: The case of Smokovo's dam in Thessaly". In Conference Proceedings, EWRA69A. $6^{\text {th }}$ International Conference 7-10/9/05. Menton. France

[10] A. Kungolos, P. Samaras, E. Koutseris. (2003): "Using bioassays for testing seawater quality in Greece". In Journal of Environmental Science and Health, eds Marcel Dekker. Inc. Reprint Program. Vol. A38. No. 533544, NY

[11] Kungolos A., Samaras P., Koutseris E. and Sakellaropoulos G.P. (2000): "Using bioassays for testing seawater quality in Greece". In Environmental Coastal Regions III, p.p. 401- 410, editors: G. R. Rodriguez, C. A. Brebbia and E. Perez-Martell. WIT Press. Southampton. UK

[12] M. Podimata, E. Koutseris and N. Tsiropoulos. (2004): "Water Quality Assessment by Ecotoxicological and Chemical Methods in Magnesia, Greece". In Water, Air, and Soil Pollution: Focus, October 2004, vol. 4, iss. 4-5, p.p. 179-187 (9) Kluwer Academic Publisher

[13] Koutseris E. (2003a): "General directions of Natura 2000-SPA regions and water resource management in Thessaly (dir.2000/60/EU): management committees and regional - agro- environmental measures in the new CAP". In Proceeding. 3rd Congress of the Development of 
Thessaly. ETHEM. Un. Thessaly. Technical Education Found. (TEF). Larissa, $12-14 / 12 / 03$, p.p. $375-393$

[14] Koutseris E. (2003b): "The new water policy: control and location of territory units with methodologies 'for a special or multiple impacts' in the small scale". In Proceedings. $3^{\text {rd }}$ Congress of the Development of Thessaly, ETHEM, UTH, TEF, Larissa, 12-14/12/03, p.p. 269-291 (in Greek)

[15] Ministry of Greek Environment (Y.PE.HO.DE. 2002): "Special environmental study". Conclusions of Dep. of natural environmental management (in Greek)

[16] Koutseris E. (2006): “Application of E.U. environmental programs in Thessaly, Greece: problems in management - protection”. Accepted to, International Journal of sustainable development editors: E. Beriatos, C. A. Brebbia and H. Itoh. WIT Press. Southampton. UK

[17] Koutseris E. (2002): "Land sustainability and spatial - environmental planning under the human nature antithesis". Doctoral Thesis. Un. of Thessaly

[18] Koutseris E., Papavassiliou. (2005): "Water as social and economic commodity: efficacy or conservation sustainability methods". In Conference Proceedings. EWRA69C. $6^{\text {th }}$ International Conference 710/9/05. Menton. France

[19] Loukissas P.; Deffner A. M.; Koutseris E.; Adamou A.; Metaxas T. (2002): "The marine Park of Northern Sporades: sustainable development, global promotion and local attachment". In Proceedings of the International Conference 'Protection and Restoration of the Environment VI' (eds. A.G. Kungolos, A.B. Liakopoulos, G.P. Korfiatis, A.D. Koutsospyros, K.L. Katsifarakis, A.D. Demetracopoulos). Skiathos, p.p. 1385- 92. July 1-5, 2002

[20] Meliadis K. (2002): Special Environmental Study and plan of management in Special Protection Area of the "mountains AntihassiaMeteora. ETHIAGE-National Inst., Prog. LIFE, Thessaloniki (in Greek)

[21] ETHIAGE. (2000): Special Environmental Study and plan of management. ETHIAGE, Special Protection Area of mount Mavrovouni of the LIFE program

[22] Christopoulou O. (2002), Network Natura 2000: Awareness and attitudes of mountain people (the case of a Greek mountain). In Discussion Paper Series, 11(8), 129 140, Un. Thessaly (dep. of P and RD) or XVI AESOP congress. Planning in Border Regions. July, 10-15, 2002. Volos. Greece

[23] PEP. (2000): Regional Operational Program of Thessaly 2000 - 2006. Special Management Service PEP. Larissa (in Greek)

[24] Koutseris E. (2006a): "Sustainable resources management in the context of agro-environmental E.U. policies: novel paradigms in Thessaly, Greece". In Proceedings of the First International Conference on the management of natural resources. Sustainable development and ecological hazards. Transaction on ecology and the environment. Vol 99, p.p. 197- 
207. Wessex. Inst. of Technology. 'The ravage of the planet'. 12-14 Dec. 2006. Bariloche. Argentina

[25] KEKANAM. (2001), Promotion of the 'Alonnissos' Northern Sporades Marine Park and Its Integration into the Social Web. ('Alonnissos' NMP. and N.S.). Prefecture of Magnesia. Lab., of Tourism. Dep., of Planning and Regional Development. Un. Thessaly (dep. of P and RD). Volos (in Greek)

[26] Ministry of Greek environment - Y.H.O.P. (1987): Special Environmental Study and plan of protection of Pelion and Northern Sporades. Y.PE.HO.DE. - YHOP., dep. of Planning. Athens (in Greek)

[27] Ministry of Greek environment, EOE. Mom. (1997): Benders Protection- Management of Pelion, Skiathos, Skopelos of the Magnessia Biotopes Program. Athens (in Greek)

[28] Koutseris E. (2005): «Climate and two-type torrential physiography: New Interdisciplinary Approaches and Discussion of Processes from Mediterranean Environmental Planning». In Conference Proceedings. EWRA69B. $6^{\text {th }}$ International Conference 7-10/9/05. Menton. France

[29] Koutseris E. (2004a): “Agriculture ou Environnement? La région d'ex lac Karla en Grèce”. In Discussion Paper, 10 (16): 407-438. Un. Thessaly. Volos

[30] Koutseris E. (2006): Protection regions and social consensus in Thessaly: the case stady of Thessaly. 'Natura 2000 - SPA' regions and water management resources, in the new prospect of rural space. Eds. Erodhios. Thessaliniki, p. 135 (in Greek)

[31] Koutseris E. (2002a): "The integrated reconnaissance in environmental protection: A new approach to planning and design". In Proceedings of the International Conference on 'Protection and Restoration of the Environment VI' (eds. A.G. Kungolos, A.B. Liakopoulos, G.P. Korfiatis, A.D. Koutsospyros, K.L. Katsifarakis, A.D. Demetracopoulos) Skiathos, pp. 1377- 84, July 1-5, 2002

[32] Koutseris E. (2004b): "Methodologies of reconnaissance and evaluation of the environmental planning impacts: for protection or conservation". In EWRA Symposium Proceedings, on 'Water Resources Management: Risks and Challenges for the $21^{\text {st }}$ Century'. Vol II, pp 903-914. Sept 2-4/9/04. Ismir. Turkey 